CONFLICT OF INTEREST IN GLOBAL, PUBLIC AND CORPORATE GOVERNANCE

Edited by

ANNE PETERS

and

LUKAS HANDSCHIN

assistant editor

DANIEL HÖGGER

圈盗 CAMBRIDGE

读得 UNIVERSITY PRESS 


\title{
Conflict of interest as a cross-cutting problem of governance
}

\author{
ANNE PETERS*
}

\section{Introduction}

Conflict of interest occurs on all levels of governance, ranging from local to global, both in the public and the corporate and financial spheres. Such conflict can influence decision-making in the management of corporations, town councils, parliaments, bureaucracies, national and international courts and tribunals, and in international conferences, organisations, and expert committees. There is increasing awareness that conflict of interest may distort decision-making processes and generate inappropriate outcomes, and thereby undermine the well-functioning of both public institutions and markets. But the current strong worldwide trend towards regulation which seeks to forestall, prevent and manage conflict of interest has its price. Drawbacks may be the stifling of decision-making processes, a loss of expertise in the person of the decision-makers and a vicious circle of distrust.

So conflict of interest abounds - or is at least perceived to abound. But what are we actually talking about? This chapter first seeks to counter the fundamental objection that the concept of conflict of interest is overbroad and meaningless (section 2). It then gives an overview of current conflict of interest regulation on all levels and spheres of governance: domestic, regional and global, and governmental and self-regulation (section 3). After recapitulating the law as it stands, the concept is probed more in depth: conflict of interest is a problem only in fiduciary (principal-agent) relationships (section 4). A typology is established: there may be a conflict between due and undue (especially personal and/or financial) interests, a conflict due to multiple roles of the agent, and a conflict arising from the

* The author thanks Lukas Handschin and Daniel Högger for useful comments on a previous version of this chapter. 
existence of multiple principals (section 5). Section 6 goes on to show that conflict of interest management is desirable to prevent corruption and bribery, which can occur in all spheres of governance: public, corporate, and global. Section 7 reviews existing scholarship on conflict of interest and explains which economic and legal phenomena have increased the potential for new forms of conflict of interest. It is then pointed out that a holistic regulatory approach involving private, administrative, and criminal law, domestic and international law, hard and soft law is obviously needed to manage the risk field of conflict of interest. However, insecurity about the correct regulatory mix, about the rules' quality, and their density persist. These questions can only be answered on the basis of cross-cutting analyses of the issue, which do not limit themselves to the traditional legal departments. Therefore, it is submitted, conflict of interest must be studied in a comparative fashion, across different levels and sectors of governance. This book seeks to implement this agenda. The purpose of this chapter is to establish a common cross-disciplinary understanding of conflict of interest, which still allows the authors of this volume, who have a background in law, sociology, social anthropology, political science, philosophy and economics, to highlight and elaborate on definitional and conceptual aspects which are particularly relevant or unique to their discipline.

\section{Conflict of interest: an elusive concept}

'Conflict of interest' as a legal term is much younger than the idea it expresses. The old adage that one cannot serve two masters describes one particular type of conflict of interest (arising out of a plurality of principals). In the judicial sphere, the requirements of independence and impartiality of the judiciary are traditional concepts for managing conflict of interest in the person of the judge. Nemo judex in re sua, no one should be a judge in his own cause, is an ancient principle which expresses this idea. Likewise, the term 'capture', when speaking of 'regulatory capture' or of 'richterliche Befangenheit' ('judicial capture'), conveys the image of a rule-maker or a decision-maker being caught by certain interest groups.

Conflict of interest has been defined as 'a situation in which some interest of a person has a tendency to interfere with the proper exercise of his judgement in another's behalf. ${ }^{1}$ The concept of conflict of interest in that

\footnotetext{
${ }^{1}$ Michael Davis, 'Conflict of Interest', p. 589. See on the notion of interest, p. 20 below.
}

sense relates to situations of decision-making with a practical relevance, such as a court's or tribunal's deliberation and adoption of a judgment, administrative activity, decisions of a board of directors of a corporation, medical decisions of a doctor, or even of surrogate decision-makers for comatose patients who lack decisional capacity. ${ }^{2}$ So the conflict we are dealing with is an intrapersonal conflict arising within a human or an institution which is entrusted with such decision-making. It is not a clash between different actors. ${ }^{3}$

Additionally, and most importantly, it is submitted here that a conflict of interest is not per se present when a professional or official decisionmaker is required to take into account various, often antagonist, interests of different sectors of society. On the contrary, a judge, a regulator, an administrator, and a company director, should consider those various interests. In fact, attempting to reconcile conflicting interests is a core element of any regulation and administration. In particular, law is what comes out when conflicting interests meet in the political arena, and is itself a tool to deal with such interests.

If all situations where a public, corporate, or professional decisionmaker takes conflicting interests into account were qualified as a 'conflict of interest', then every assessment of costs and benefits, and every balancing decision would involve a conflict of interest. Such an (overly) broad conception then leads to the misleading statement that every decision-making based on consequentialist moral reasoning (and hence on an estimation of the relevant costs and benefits) necessarily implies a conflict of interest for the decision-maker. ${ }^{4}$

But such a broad definition, on such a high level of abstraction, does not help in the understanding of the issue. If any decisions subject to multiple objectives were described as conflicted, there would be hardly any non-conflicted settings left. ${ }^{5}$ The concept's explanatory value would be reduced to zero.

It is therefore preferable to pitch the concept less broadly. For example, the EU implementing Directive on investment firms of 2006 mentions 'detrimental' conflict of interest, and thereby implies that

${ }^{2}$ See Shapiro, 'Conflict of interest at the bedide: surrogate decision-making at the end of life', Chapter 18 in this volume.
lon

3 Conflicts between different actors are the theme of Axeirod, Conflict of Interest. The present book has nothing to do with such conflicts.

${ }_{4}^{4}$ See in that sense Frank, 'Conflict of Interest', pp. 270-271.

See Issacharoff, 'Legal Responses', p. 191. 
some conflicts may be neutral or benign. ${ }^{6}$ A different terminology for distinguishing 'ordinary' situations from detrimental ones might be to call the former one of 'conflicting interests' (mostly vested in diverse actors or groups confronting each other). ${ }^{\text {? }}$

Contrary to the terminology suggested here, Jean-Bernard Auby, in this volume, espouses a broad notion of conflict of interest which encompasses situations in which the administrator balances conflicting interests. ${ }^{8}$ Erhard Friedberg likewise criticises the distinction between 'conflict of interest' and 'conflicting interests.' For him, the concept of conflict of interest includes three key elements: the existence of different spheres of action, the idea of 'bridging, brokering, coordinating of positions' that are at the intersection of these spheres of action; and thirdly, the 'use of resources drawn from one sphere of action to gain influence in the other. ${ }^{10}$ Friedberg objects that the 'essentialist orientation' of distinguishing 'conflict of interest' and 'conflicting interests' does not contribute to the understanding of the phenomenon.

Admittedly, my distinction excludes from scrutiny a large bulk of situations, and risks to reify constellations where conflicting interests might run or not run into a situation of conflict of interest in the narrow sense. On the other hand, a broad notion of conflict of interest leads to finding conflict of interest everywhere in social life. It is no coincidence that the author who espouses such a broad notion finds that the issue (broadly as he conceives it) is largely one of perception and one which cannot be eliminated. The real problem is, according to Friedberg, controlling the behaviour of those who benefit from their position. So rather than pursue a definitional search, it is perhaps more useful to identify a legally significant conflict of interest, a conflict in which the risk of inappropriate judgements - or in the perspective of the principal-agent theory, the risk of agency opportunism - is most acute. ${ }^{11}$

${ }^{6}$ Art. 23 of Commission Directive 2006/73 of 10 August 2006 implementing Directive 2004/39/EC of the European Parliament and the Council as regards organisational requirements and operating conditions for investment firms and defined terms for the purposes of that Directive (O) 2006 L 241/26).

7 Margolis, 'Conflict of Interest', gives Antigone as the classic example of a person subjected to conflicting interests, or conflicting obligations. She is torn between king Kreon's commands (to leave the brother unburied) and her obligation towards the gods (to bury the brother) p. 361.

8 See Auby, 'Conflict of interest and administrative law', Chapter 8 in this volume.

9 See Friedberg, 'Conflict of interest from the perspective of the sociology of organised action', Chapter 2 in this volume, pp. 40-41.

${ }^{10}$ Ibid., p. $41 .{ }_{11}^{11}$ Issacharoff, 'Legal Responses', p. 191.

\section{Proliferation of conflict of interest regulation}

Regulation of conflict of interest has recently been proliferating, both on the level of national legislation, and on the level of global governance. In many countries, traditional patterns of self-regulation in the professions have been complemented or substituted by statutory conflict of interest legislation.

\subsection{Regulation on the domestic level}

The United States is probably the country with the oldest and today most developed conflict of interest regulation. ${ }^{12}$ In 2006, a new law, the Honest Leadership and Open Government Act was adopted in the US. ${ }^{13}$ In the same year, Canada enacted a comprehensive modern conflict of interest statute, which is frequently referred to as a model. ${ }^{14}$

With regard to the EU member states, the main empirical findings of a comparative study of $2007^{15}$ are as follows: most states have different and separate rules on conflict of interest for their different institutions. Only rarely are there specific conflict of interest rules applying to the entire government sector. An example is the Seven Principles of Public Life, a not strictly binding code for all UK government officials. The first principle is 'selflessness', and states: 'Holders of public office should act solely in terms of the public interest. They should not do so in order to gain financial or other benefits for themselves, their family or their friends. ${ }^{16}$

The new EU member states are generally more regulated than the old member states, with Latvia and Bulgaria, followed by Poland and Romania, having the highest regulation density in Europe, based on the

12 The first law that we would now think of as a conflict of interest law was Part 2 of the Act to prevent Frauds upon the Treasury of the United States of 1853 (18 USC $\S 283,10$ Stat 170). According to the Office of Government Ethics, Report to the President and to Congressional Committees on the Conflict of Interest Laws Relating to Executive Branch Employment (Washington DC, January 2006), p. 3, this law was the first attempt to address the ethical problems that arise when a public employee misuses his official position to benefit his private clients.

13 Honest Leadership and Open Government Act of 14 September 2007 (Public Law 110-181; 121 Stat 735). See for federal employees the US American Government Ethics Reform Act of 30 November 1989 (Public Law 101-194).

14 Conflict of Interest Act, Statutes of Canada 2006, chapter 9, section 2, in force since 9 July 2007, last amended on 11 July 2011.

15 Demmke et al., Regulating Conflicts of Interest.

16 Adopted by the Committee on Standards in Public Life. Available at www.public-standards. gov.uk/About/The_7_Principles.html (last accessed 15 December 2011). 
US model. ${ }^{17}$ Among the old member states, Portugal is highly regulated, followed by the UK and Spain. Italy ${ }^{18}$ and Turkey ${ }^{19}$ have recently enacted or thoroughly revised regulation in the field. Countries with the least conflict of interest issues regulation are Austria, Denmark and Sweden.

Following Demmke et al., four types of existing 'hard' regulation on conflict of interest can be distinguished. First, relevant provisions are found in laws applying to all institutions of a given state, such as the constitution, the penal code, the laws on the administration, or the civil service act. Secondly, the general statutes for specific institutions, such as central bank acts, or court of auditors acts may contain provisions relevant for managing conflict of interest. Thirdly, states have adopted specific legislation on conflict of interest applicable to all institutions in a state, such as the Slovenian Prevention of Corruption Act, ${ }^{20}$ or the Irish Ethics in Public Office Act. ${ }^{21}$ Finally, states have enacted specific conflict of interest rules applicable to individual institutions, for example the Austrian Incompatibility Act for Government and Parliament. ${ }^{22}$

As to the institutional comparison in Europe, the highest regulatory density can be found with regard to the national central banks and for governments, the former institutions being often regulated by codes of ethics only. Parliaments are the least regulated institutions. ${ }^{23}$ The comparative study by Demmke et al. concludes that parliaments are in part structurally under-regulated. ${ }^{24}$

${ }^{17}$ Demmke et al., Regulating Conflicts of Interest, pp. 43 and 48. Demmke et al. consider these states to be perhaps over-regulated. See the country profiles of twenty-seven EU member states in ibid., pp. 157 et seq., on Bulgaria pp. 172-178; on Latvia pp. 244-253.

${ }_{18}$ Legge $\mathrm{n} 215$, Legge in material di risoluzione dei conflitti di interessi (Rules for the resolution of conflicts of interest, the 'Frattini Law') of 20 July 2004, Gazetta Ufficiale No. 193 of 18 August 2004; English translation in Council of Europe, Venice Commission, Opinion No. 309/2004, Doc. CDL(2004)093rev. The law only deals with conflict of interest of persons holding government office (such as the Prime Minister and ministers).

19 Law No. 5176 related to the Establishment of a Council of Ethics for Public Service and Making Modifications on Some Laws of 25 May 2004. Available at www.tbmm.gov.tr/ etik_komisyonu/belgeler/kanun_5176_eng.pdf (last accessed 15 December 2011). The Council of Ethics prepared ethical guidelines which were adopted in form of a regulation by the Prime Ministry on 13 April 2005 (Regulation on the Principles of Ethical Behaviour of the Public Officials and Application Procedures and Essentials, No. 25785, Official Gazette of 13 April 2005. Available at www.etik.gov.tr (last accessed 15 December 2011).

20 Resolution on the Prevention of Corruption in the Republic of Slovenia (RePKRS) of 16 June 2004, No. 212-05/04-33/1

${ }_{21}$ Ethics in Public Office Act of 22 July 1995, No. 22 of 1995 (Irish Statute Book)

${ }^{22}$ Demmke et al., Regulating Conflicts of Interest, p. 26.

23 Ibid., p. $48 .{ }_{24}^{2}$ Ibid., p. 49.
As to specific conflict of interest-related principles and issues, the rules on impartiality, on the incompatibility of posts, and on loyalty are most often codified, and financial disclosure is also well regulated. ${ }^{25}$ In contrast, the field of post-employment is least regulated. In this regard, rules in some European states, in the US (strong regulation), and in Canada differ considerably. This issue is probably under-regulated. ${ }^{26}$

Legal comparison reveals that France stands out. Here, legislation relating to conflict of interest appears outdated. The preventive aspect is not developed; the existing French norms focus on repression, and even those norms are rarely applied in practice. Against this background, the French President in 2010 established a 'Commission of reflexion on the prevention of conflict of interest in public life'. Under the heading 'towards a novel deontology of public life', the commission's report highlighted glaring lacunae in the French legal system and strongly urged for reforms. ${ }^{27}$ Recent French scholarship has pressed in the same direction. ${ }^{28}$ In this volume, two French contributions analyse the issue from a legal and sociological perspective, respectively. ${ }^{29}$

\subsection{Global and European benchmarks for states}

Conflict of interest has become a matter of international concern. For example, the UN General Assembly has, in the course of its action against corruption, adopted an 'International Code of Conduct for Public Officials' in 1996. The Code's first principle is that a 'public office, as defined by national law, is a position of trust, implying a duty to act in the public interest. ${ }^{30}$ Principle 2 of that Code deals at length with conflict of interest and disqualification. Furthermore, the Council of Europe adopted a set of recommendations for national public administrations. ${ }^{31}$ The Organisation for Economic Co-operation and Development (OECD) has published a

${ }^{25}$ Ibid., pp. 52, 55, $57 . \quad{ }^{26}$ Ibid., pp. 55-59.

27 Commission de réflexion pour la prévention des conflits d'intérêts dans la vie publique, Pour une nouvelle déontologie de la vie publique (26 January 2011). The three-person Commission was chaired by Jean-Marc Sauvé, vice-president of the Conseil d'Etat, and consulted sixty individuals, who are listed in an annex to the report.

${ }^{28}$ Hirsch, Pour en finir avec les conflits d'intérêts.

29 Auby, 'Conflict of interest and administrative law', Chapter 8; Friedberg, 'Sociology of organised action', Chapter 2 in this volume.

30 Annex to General Assembly resolution $51 / 59$ of 12 December 1996, para. 1.

${ }^{31}$ Council of Europe recommendation on Codes for public officials, Recommendation No. R (2000) 10 E, of 11 May 2000, Art. 13 - Conflict of interest. 
'toolkit,' 32 and entertains an 'Observatory on Ethics and Codes of Conduct in OECD Countries.'." Moreover, the European Union (EU) has commended the above-mentioned comparative study of the Rules and Standards of Professional Ethics for the Holders of Public Office in the EU-27. ${ }^{34}$

The EU Directive on Markets in Financial Instruments (MiFID) of 2004 obliges the EU member states to require investment firms to take all reasonable steps to identify conflicts of interest between themselves (including their managers, employees and tied agents and persons under the firms' control) and their clients, or between one client and another, that arise in the course of providing investment services, and to maintain and operate organisational arrangements so as to prevent them. MiFID and its implementing directive also provide that, where organisational or administrative arrangements to manage such conflict of interest are not sufficient, the investment firm must disclose the nature and/or the source of the conflict to the client before undertaking business. ${ }^{35}$ MiFID also obliges member states to require that investment firms take all reasonable steps to obtain the best possible results for their clients, and thus indirectly enshrines a fiduciary obligation of loyalty. ${ }^{36}$

\subsection{Self-regulation of global and European institutions}

Recently, the international institutions have realised that conflict of interest is a vital issue for themselves and a problem not only of domestic but of supranational and global governance as well. ${ }^{37}$ For example, the UN General Assembly in 2005 urged the Secretary-General to develop a UN system-wide Code of Ethics. ${ }^{38}$ This code should become the principal document outlining the ethical standards to be upheld by United

${ }^{32}$ Organisation for Economic Co-operation and Development (OECD), Managing Conflict of Interest.

33 Available at www.oecd.org/document/57/0,3746,en_34645207_34744738_35521657_1 1_1_1,00.html (last accessed 15 December 2011).

34 Demmke et al., Regulating Conflicts of Interest.

${ }_{35}$ Demmke et al., Regulating Conflicts of Interest. $\mathrm{EC}$ of the EP and the Council of 21 April 2004), OJ 2004 L 145/1; implementing Directive 2006/73 of 10 August 2006 (OJ 2006 L 241/26), Arts. 21-23: conflict of interest potentially detrimental to clients; conflict of interest policy; and record of services or activities giving rise to detrimental conflict of interest.

${ }^{36}$ Art. 21 MiFID.

37 See in detail Nganga Malonga, 'Conflict of interest of international civil servants', Chapter 4 in this volume.

${ }^{38}$ See 2005 'World Summit Outcome Document' (GA Res. 60/1 (2005)), and 'Review of the efficiency of the administrative and financial functioning of the United Nations'
Nations personnel and should complement the International Civil Service Commission (ICSC) standards of conduct which date from 2002. ${ }^{39}$ The United Nations established an independent Ethics Office in the UN Secretariat, which commenced operation in $2006,{ }^{40}$ and which produced the requested draft Code. ${ }^{41}$ The UN Secretary-General in 2011 published a report on conflict of interest of UN staff. This report highlights that staff are increasingly faced with competing interests that may have an impact on their impartiality, and that managing conflict situations must become a priority for the world organisation. ${ }^{42}$

Other international organisations have tackled the issue in their staff rules (such as the OECD), ${ }^{43}$ or in codes of conduct - such as the IMF,

(GA Res. 60/254 (2006)). See on this Code of Ethics, Auguste Nganga-Malonga, 'Conflict of interest of international civil servants', Chapter 4 in this volume, pp. 67-68.

39 See Report of the International Civil Service Commission for 2009, UN Doc. A/64/30 (2009), paras. 24-29. See also the UN Staff Regulations of 7 February 2003 (Doc. ST/SGB/ 2003/5), Art. I - Duties, obligations and privileges, Regulation 1.2: Conflict of interest: ' $(\mathrm{m})$ 2003/5), Art. I - Duties, obligations and privileges, Regulation 1.2: Conflict of interest: (m) interest in, any profit-making, business or other concern, if it were possible for the staff member or the profit-making, business or other concern to benefit from such association or financial interest by reason of his or her position with the United Nations'.

40 Established pursuant to the 2005 World Summit Resolution (GA Res. 60/1, para. 161(d)).

41 See Annex 'Code of Ethics for United Nations Personnel', to: Activities of the Ethics Office, Report of the Secretary-General, UN Doc. A/64/316 (2009). This draft has not yet been adopted by the General Assembly.

42 'Personal conflict of interest: Report of the Secetary-General', UN Doc. A/66/98 (27 June 2011).

43 OECD, Staff regulations, rules and instructions applicable to officials of the Organisation, October 2008, Title II - Basic principles, rights and duties independence and international character, Regulation 2: '(a) The duties of officials of the Organisation are international in character. Officials are subject to the authority of the Secretary-General, and are responsible to him for the discharge of their dutties. (b) Officials shall carry out their duties and regulate their conduct always bearing in mind the interests of the Organisation and the international character of their duties. (c) Officials shall neither seek nor accept from any Member country of the Organisation or any source external to the Organisation any instructions. Unless authorised to do so, they shall neither seek nor accept, any: (i) gratuity or benefit in connection with their official duties or by reason of their status as an official of the Organisation; (ii) honorary distinction; or (iii) remuneration', Regulation 3(a): 'Officials shall: (i) carry out their duties in accordance with the highest standards of integrity and loyalty; (ii) conduct themselves with objectivity and impartiality and avoid any conflict of interest, or appearance of conflict of interest, in the performance of their duties' (emphases added).

in the performance of their duties' (emphases added).
${ }_{44}$ International Bank for Reconstruction and Development (IBRD), the International Finance International Bank for Reconstruction and Development (IBRD), the International Finance
Corporation (IFC), the International Development Association, and the Multilateral Investment Guarantee Agency (MIGA): Code of conduct for board officials, effective as of 1 November 2007, which contains a section B 'Conflict of interest policy' (Arts. 6-10) (adopted by the respective Executive Directors of all four universal financial organisations). 
which also established an IMF Ethics Officer. ${ }^{45}$ The International Law Association, a worldwide association of professionals, has recently suggested ethical standards for legal counsels which include conflict of interest rules for counsels appearing before international courts and tribunals. ${ }^{46}$

On the level of supranational regional administration, the EU has tightly regulated conflict of interest for its own officers and staff. EU institutions have adopted more than ten different codes to regulate conflict of interest with regard to different groups of office-holders. ${ }^{47}$ For example, the members of the EU Commission are subject to a Code of Conduct, adopted in 2011, which, inter alia, prescribes the declaration of any financial and other interests, the non-financial ones (such as previous activities and outside activities) being made public. ${ }^{48}$ The EU Commission staff also has a code of good administrative behaviour. The very first guideline of this staff code reads: 'Staff shall always act objectively and impartially, in the Community interest and for the public good ... [T] heir conduct shall never be guided by personal or national interest or political pressure. ${ }^{49}$ Also the European Parliament's Rules of Procedures of 2011 contain a rule on members' financial interests, standards of conduct, and a mandatory transparency register. ${ }^{50}$ The rules also prescribe that '[b] efore speaking in Parliament or in one of its bodies or if proposed as rapporteur, any Member who has a direct financial interest in the subject under debate shall disclose this interest to the meeting orally. ${ }^{51}$ The ECJ has adopted a code of conduct for members of the Court which, inter alia, prescribes the declaration as to financial interests and regulates post-employment. ${ }^{52}$ Finally, EU staff regulations explicitly regulate conflict of interest: 'Impartiality is a fundamental principle of public service which is

${ }^{45}$ Terms of reference of 12 June 2008.

46 International Law Association Study Group on the Practice and Procedure of International Courts and Tribunals, The Hague Principles on Ethical Standards for Counsel Appearing before International Courts and Tribunals, 27 September 2010, principle 4. Available at www.ucl.ac.uk/laws/cict/docs/Hague_Sept2010.pdf (last accessed 19 December 2011).

47 See in detail Demmke et al., Regulating Conflicts of Interest, pp. 60-66.

${ }^{48}$ Code of Conduct for Commissioners (C (2011) 2904), of 20 April 2011, Arts. 1.3, 1.5 and 1.6.

${ }^{49}$ Code of good administrative behaviour for staff of the European Commission in their relations with the public, Commission decision of 17 October 2000 amending its Rules of Procedure, Annex (2000/633/EC, ECSC, Euratom), Of 2000 L 267/63.

${ }^{50}$ EP, Rules of Procedure, 7th parliamentary term, July 2011, Rule 9.

${ }^{51}$ Ibid., Annex I, Art. 1.

${ }^{52}$ Court of Justice, Code of Conduct (OJ 2007 C 223/01), Arts. 4 and 6. recognised by the Charter of Fundamental Rights of the European Union. It is therefore vital to clarify the obligations of officials in situations where there is an actual or potential conflict of interest, both before and after leaving the service. ${ }^{253}$

The proliferating conflict of interest regulation is embedded in new transparency requirements and has given rise to new forms of accountability. Concomitantly, new ethics bureaucracies have emerged which might themselves be reproached for lacking transparency and disregarding privacy. ${ }^{54}$

\section{Conflict of interest and the fiduciary relationship}

Crucially, conflict of interest is a problem only with regard to decisions made for someone else (the client or the public). ${ }^{55}$ A conflict of interest surfaces not in every situation where a person has to respect - passively various interests. What is needed is an obligation to defend actively the interests of others. If this were not a pre-condition for using the concept of conflict of interest, then conflict of interest could not be distinguished from a simple abuse of rights. ${ }^{56}$

\subsection{Agency and trust}

The situation is mostly analysed as a principal-agent relationship in which the agent first has the legal power or authority to take valid decisions on behalf of another person (the principal), and where he, secondly, bears a fiduciary duty towards that principal. The fiduciary duty may, in the private law world, arise from law, from contract, or flow from professional standards (self-regulation of the profession). In the public sphere, the fiduciary duty flows from the constitution, from law, or from the concept of public office ('Amt'). In such a fiduciary (or principal-agent) relationship, the interest which has given rise to the empowerment of the agent is never completely identical to the interest of the agent who holds the power to act.

53 Art. 14 of Council Regulation (EC, Euratom) No. 723/2004 of 22 March 2004 amending the Staff Regulations of officials of the European Communities and the Conditions of Employment of other servants of the European Communities (OJ 2004 L 124/1).

${ }_{54}$ Demmke et al., Regulating Conflicts of Interest, p. 7.

${ }_{55}$ Issacharoff, 'Legal Responses', p. 189; Simonart, 'Conclusions', pp. 308-309.

${ }^{56}$ Simonart, 'Conclusions', p. 304 
Besides the concept of 'agency', the common law institution of 'trust' is used to describe the relationship between principal and agent, both in the private and the public sphere. Already John Locke famously argued that 'the legislative being only a fiduciary power to act for certain ends, there remains still in the people of supreme power to remove or alter the legislative, when they find the legislative to act contrary to the trust reposed in them. ${ }^{37}$ The influential OECD guidelines on conflict of interest conceptualise officeholders as trustees to the state and to the citizens. ${ }^{58}$ In a formalistic legal perspective, this parallel terminology is confusing, because probably most legal traditions distinguish agency from trust (or have invented institutions to distinguish two types of relationship). A trustee is less constrained by his trustor, and enjoys discretion, whereas an agent is more tightly controlled and has less or no leeway. Be that as it may, in a sociological perspective, there is a continuum between agency and trust. ${ }^{59}$ Both terms seem appropriate to describe the special (fiduciary) relationship between the actor and the other on whose behalf he acts. To conclude, fiduciary relationships are generally recognised in all spheres of law, private (corporate), public, and global law. Even though these relationships are in technical terms made concrete with help of different legal devices, and carry different names, their structure is comparable. In any case, the two basic forms by which a conflict of interest in the person of the agent can materialise is that he either oversteps the limits of his authorisation (mandate) and acts ultra vires, or that he abuses his power. ${ }^{60}$ Both types of illegal action are acknowledged and regulated in private and in public law in different legal systems. ${ }^{61}$

${ }^{57}$ John Locke, Two Treatises of Government, para. 149, p. 413.

${ }^{58}$ OECD, Managing Conflict of Interest, p. $16 . \quad{ }_{59}$ Cf. Shapiro, Tangled Loyalties, p. 18. ${ }^{60}$ Simonart, 'Conclusions', pp. 310-312.

${ }^{61}$ See on abuse of powers in administrative law, Peters, 'Managing conflict of interest: lessons from multiple disciplines and settings', Chapter 19 in this volume, pp. 366-368. See for the sphere of public governance, for example in English administrative law, Hilaire Barnett, Constitutional \& Administrative Law, p. 736: "If an authority "takes into account irrelevant considerations which materially affect the decision reached", [it] may be held to be acting ultra vires.' See for the sphere of private law the rules on ultra vires action of company directors, on consequences for legally binding the company and on the internal liability of the directors, e.g. in s. 40(1) of the English Companies Act 2006; for Switzerland Art. 718a of the Codes des Obligations; for France L. 223-18 (6) Code de Commerce, and for the EU Art. 9 of Directive 2009/101/EC, OJ 2009 L 258/11-19. See in scholarship on ultra vires contracting of corporate agents in company law Davis, Worthington and Micheler, Gower and Davies' Principles of Modern Company Law, MN 7-3. Finally, see for an example of ultra vires action in global governance the instances where the United Nations General Assembly ostensibly overstepped its powers
Building on the principal-agent theory, Guido Palazzo and Lena Rethel have further distinguished 'personal' (or 'individual') from 'impersonal' (or 'organisational') conflict of interest. An individual conflict of interest is due to the professional's behaviour, and located in the principal-agent relationship, whereas an organisational conflict of interest is due to the organisational structure. ${ }^{62}$ However, both types can overlap. An example in the financial sphere is 'late trading. Whenever single employees promise late trading to a certain client, there is a conflict between the interest of that client and those of others. But 'late trading' can also be inherent to a financial intermediary's common practice and then constitute an organisational conflict. ${ }^{63}$

\subsection{Fiduciary obligations}

The most general fiduciary duties are the obligation to act in the best interest of the principal and the duty of loyalty. For example, Article 717 Swiss Civil Code obliges the members of the board of directors and the executives of a stock corporation (société anonyme) to exercise their mandate with 'all necessary due diligence' and 'faithful to the interests of the company.64 This provision fits into the civil law tradition of corporate law which has indeed conceptualised such an 'interest of the company'. The company's interest is, in that legal framework, the sum of all interests which the management has to observe when acting on behalf of the company. It is based (and focuses) on the shareholder interest, but includes also (to a lesser extent) the interests of other stakeholders, in particular the creditors of the company. In contrast, in Anglo-American legal orders, the obligations of management are defined with a view to

(IC), Legal Consequences of the Construction of a Wall in the Occupied Palestinian Territory, Advisory Opinion, ICJ Reports 2004, 136, paras. 24-35).

62 Palazzo and Rethel 'Conflicts of Interest', p. 12,63 Ihid, p. 15.

64 Art. 171 CO: '1 Les membres du conseil d'administration, de même que les tiers qui s'occupent de la gestion, exercent leurs attributions avec toute la diligence nécessaire et veillent fidèlement aux intérêts de la société. 2 Ils doivent traiter de la même manière les actionnaires qui se trouvent dans la même situation.' (Loi fédérale complétant le Code civil suisse, Livre cinquieme: Droit des obligations) of 30 March 1911, in this wording since 1 July 1992. See also Art. 20 of the Loi fédérale du 23 juin 2006 sur les placements collectifs de capitaux (LPCC, RS 951.31). However, judicial scrutiny of such provisons is usually deferent. Courts typically do not find any liability of managers. See for a detailed analysis Bahar and Morand, "Taking conflict of interest in corporate law seriously - direct and indirect rules addressing the agency problem?, Chapter 17 in this volume. 
specific principals, normally the shareholders' ('shareholderism'). Employees or creditors do not play a part here, or only marginally. ${ }^{65}$

Similarly, the relevant EU Directive on undertakings for collective investment in transferable securities prescribes that ' $[n]$ o single company shall act as both investment company and depositary' and that ' $\mathrm{i}$ ] $\mathrm{n}$ carrying out its role as depositary, the depositary must act solety in the interests of the unit-holders. ${ }^{66}$

A different regulatory technique to the same end is stipulating the responsibility of the agent towards the principal. To illustrate this technique, an example can be taken from the sphere of global governance. Article 100 of the Charter of the United Nations of 1945 holds: 'In the performance of their duties the Secretary-General and the staff shall not seek or receive instructions from any government or from any other authority external to the Organization. They shall refrain from any action which might reflect on their position as international officials responsible only to the Organization.

\subsection{Extensions of fiduciary obligations as a source of conflict of interest}

From the perspective of the principal-agent theory, an important question is who the principal actually is (or who should alternatively be regarded as a rightful principal for normative reasons), because this matters for the assessment of the relevant interests and for the disqualification of some (or rather someone's) interests as undue or not. For example, there seems to be a current trend (however quite uneven in different legal traditions) of corporate governance to perceive the firm not only as responsible towards the shareholders but also towards stakeholders. ${ }^{67}$ Notably Anglo-American corporate law traditionally held the shareholder's interests as primary. Under the heading of 'shareholder primacy', or 'shareholder value', it was agreed that the objective of corporations should first of all or exclusively be to maximise shareholder wealth. This view was in the 1980s challenged by the 'stakeholder theory' which claimed that shareholders are only one of many competing and diverse groups that have an interest in the affairs of a company, including employees, customers, suppliers, creditors, investors,

65 See on shareholderism and stakeholderisms text accompanying FN 68 below.

${ }^{66}$ Art. 17 of the Council Directive of 20 December 1985 on the coordination of laws, regulations and administrative provisions relating to undertakings for collective investment in transferrable securities (UCITS Directive), 85/611/EEC, OJ 1985 L 375/3.

67 See a useful sceptical overview by Keay, 'Moving Towards Stakeholderism?'. and the local and national government. ${ }^{68}$ All social groups who are affected or might be affected by a company's decisions are in that view the company's stakeholders. The idea is then that managers must at least take into account and balance the interests of all these stakeholders in their business decisions. In a more extreme form of stakeholderism, these persons have genuine rights, and must be allowed to participate in corporate decision-making. As far as employees are concerned, this is realised notably in German corporate law (regime of codetermination), and also in Japan. The stakeholder theory is directly relevant for assessing conflict of interest management in corporate governance, because it determines whose interests may and even must be duly taken into account, and whose interests would be 'undue' in the sense described above. Along the line of 'stakeholderism', public opinion and the media in a vague and untechnical sense are more and more inclined to assume that (big) business must also further some kind of 'public' interest. This ongoing expansion of corporate duties of loyalty 'creates stress', as corporate lawyers have rightly pointed out. ${ }^{69}$ The broader the group of stakeholders becomes, the more the fiduciary duty of loyalty is expanded, the more difficult it becomes to distinguish due from undue interests, and the greater is the potential for conflict of interest.

The same trend is visible with regard to certain professions which are formally regulated by private law, and which are exercised by private actors, but where diligent performance is highly relevant for society at large. For example, engineers or accountants have individual (private) clients, but they also bear a responsibility to the public. While they are not contractually responsible towards society, it might be said that in a sociological sense their private-party principals are replaced either wholly or partially with the public. ${ }^{70}$

Finally, a parallel debate is taking place in the sphere of global governance where it is asked whether international organisations should be directly accountable to citizens, and not only to member states. This would encompass, inter alia, holding them liable for human rights violations, and also lifting or restricting their immunity before national courts. ${ }^{71}$

68 Seminally Freeman, Strategic Management.

69 Thévenoz and Bahar, Conflict of Interest p. 7. It has also been criticised that the talk of 'stakeholders' is a means to escape accountability towards minority shareholders.

70 Stark, 'Comparing Conflict of Interest across the Professions', p. 343

${ }_{71}$ Peters, 'The Constitutionalization of International Organizations'. 


\subsection{Comparative conclusions}

To sum up, fiduciary relationships, which are at the origin of conflict of interest, exist in all branches of law, and in all spheres of governance. Within such relationships, the decision-makers ('agents') are expected to make decisions according to the established and accepted standards (legal, professional and ethical) and in fulfilment of their institutional role. They owe professional (contract-based) and/or legal or constitutional obligations towards certain groups (their clients or 'principals'), notably general obligations of loyalty. Interests of other groups (or of the decision-maker himself) may have an impact on either the decision-making process or on the outcome or on both. Decision-making processes and outcomes which are 'tainted' by that impact constitute a breach of the fiduciary obligations. The ongoing, but controversial trend, in various spheres of governance, ranging from corporate law to the law of international organisations, to expand fiduciary obligations (or at least moral responsibilities), beyond concrete main principals so that they might exist vis-à-vis other groups or to the public at large, and the controversies about who the rightful principals should be, give rise to new types of conflict of interest.

\section{Typology}

In practice, regulators have addressed typical conflict of interest constellations, notably accepting benefits (gifts etc.); outside employment or other outside activities, post-employment, self-dealing, 'influence peddling, ${ }^{72}$ using government property and using confidential information. With regard to legal representatives (e.g. solicitors), the following constellations of conflict of interest have been identified: the existing client conflict (in simultaneous representation), the former client conflict (in the event of successive representation), and the personal conflict (i.e. the conflict between client's interest and personal interest). ${ }^{73}$ Upon examination it becomes apparent that these constellations are structured differently. Both the underlying 'conflict' and the underlying 'interests' differ. In more abstract terms, three types of conflict of interest, which overlap, can be distinguished.

72 'Influence peddling' (or 'trading in influence') is the situation where a person in a position of power possesses confidential information or simply has useful connections which he exploits to give an improper advantage to another organisation or person.

${ }^{73}$ Hollander and Salzedo, Conflicts of Interest, pp. 1-4.
5.1 The conflict between due and undue interests

As stated above (p. 5), not every intra-personal conflict of interest is legally relevant. A conflict of interest in the narrower sense, the subject of this book, is present only when there is a peculiar kind of conflict which has to do with the nature of the interests conflicting, and with their relationship in the concrete context. ${ }^{74}$

The canonical OECD definition of a public-sector conflict of interest holds that the conflict arises when public officials have private-capacity interests 'which could improperly influence the performance of their duties. ${ }^{75}$ Similarly, the recent Code of Conduct for members of the British government states that the government should 'act in the national interest, above improper influence. ${ }^{76}$ Here we find an implicit distinction between proper and improper influence, and - one could add - between proper and improper interests coming into play. Along the same line, the Council of Europe Criminal Law Convention on Corruption obliges state parties to criminalise the promising, giving, or offering, of any undue advantage to anyone asserting or confirming 'that he or she is able to exert an improper influence over the decisionmaking' of public or private decision-makers. ${ }^{77}$ This provision, although directed at one specific form of corruption, namely trading in influence, again presupposes that there are proper and improper factors (or interests) which might influence decision-making.

Granted, there are no a priori illegitimate or 'improper' or 'undue' interests in a society. Nevertheless, some interests may, in a concrete context, not be reasonably connected to the decision at hand to be taken. Then these interests are in that specific context undue, inappropriate, or alien, and may constitute an 'improper' influence, as the OECD toolkit and the UK Ministerial Code, both cited above, put it.

${ }^{74} \mathrm{Cf}$. Margolis, 'Conflict of Interest', p. 362: 'Where ... we have a conflict of interest, one or the other interest may not be independently legitimate... In a conflict of interest, it is then, precisely the relationship of the putative interests that is essential' (emphasis added).

75 OECD, Managing Conflict of Interest, p. 7 (emphasis added). The French wording is 'susceptible d'influencer indûment l'exécution des obligations'. Referring to this definition, the French Commission de teflexion highlights that the inters must be susceptible to impact unduly on the fulfilment of the obligations of a public official (Commission de réflexion (n 28), p. 16).

${ }^{76}$ UK, Ministerial Code, Cabinet Office, May 2010 (emphasis added).

77 Art. 12 of the Council of Europe Criminal Law Convention on Corruption, ETS No. 173 (27 January 1999) (emphasis added). 
These are called 'alien factors' or 'alien interests' in US administrative law, ${ }^{78}$ or 'sachfremd' to use a German term.

Based on this insight, we can identify as a first type of conflict of interest (in the narrow sense) the conflict between due and undue interests which may influence the decision-making process and its outcome. ${ }^{79}$ In principalagent analyses of conflict of interest, the principal's interest is often called the 'primary' interest, that is the interest which should 'officially' be pursued by the agent. The agent has his 'secondary' interest. ${ }^{80}$ The agent may be a professional or an office-holder. The principal may be a client in a private law relationship, or - for holders of public office - the public.

What are these interfering 'secondary' and in the concrete context 'undue' interests? 'Interest' has been defined as 'any influence, loyalty, concern, emotion, or other feature of a situation ${ }^{81}$ or as comprising 'financial gains' and 'other personal benefits which might be psychological, social, or political. ${ }^{32}$ So the secondary interest may be financial or personal (such as the pursuit of professional advantages), but also the desire to favour friends, family, colleagues or students.

A typical source for a conflict of interest of this type arises from the decision-maker's membership or affiliation to particular groups. ${ }^{83}$ Such relations - be they of a family, business, or otherwise social nature - are prone to giving rise to conflicts because they suscitate the decisionmaker's desire to favour the involved persons themselves or the interests they represent, and thereby interfere with his or her judgement.

In all spheres of governance, legal norms, codes of conduct, and self-regulatory instruments contain standard formulas which seek to prevent actual interference of the alien interest with the judgement, and also the appearance of this. To give but an example from the legal profession (thus the private-law sphere), statutes on legal counsels usually stipulate that counsels should exercise their profession in due

${ }^{78}$ Fehling, Verwaltung zwischen Unparteilichkeit und Gestaltungsaufgabe, pp. 20-21 and p. 506, with further references.

79 This is similar but not identical to what Andrew Stark has called an 'out of role conflict' (Stark, 'Comparing Conflict of Interest', pp. 335-336).

${ }^{80}$ Institute of Medicine (IOM), Conflict of Interest in Medical Research, Education and Practice. See Davis, 'Empirical research on conflict of interest: a critical look', Chapter 3 in this volume.

${ }^{81}$ Davis, 'Conflict of Interest', p. 590. $\quad{ }^{82}$ Hejka-Ekins, 'Conflict of Interest', p. 482

83 These groups may be outsiders to the principal-agent relationship, but they might also be the principals themselves (such as clients of a professional or the parties to a law suit to be decided by a judge). diligence and should avoid any conflict of interest between the interests of their clients and those of other persons to whom they stand in a business or private relationship. ${ }^{84}$

With regard to the sphere of public governance, some additional observations can be made. The situation where officials use their public office in order to satisfy private interests might be called 'top down' conflicts. This affects the 'output' side of democratic governance. In contrast, 'bottom-up' conflicts of interest are present when a candidate exploits private interests (especially through campaign funding) in order to acquire an elected office. This affects the 'input' side of democratic governance. ${ }^{85}$

In the background of the uncertainty of the concept about conflict of interest in the public sector are divergent conceptions of the public office, and concomitantly of the 'public interest'. In the French tradition the official is deemed impermeable for private interests. He is - as an ideal type - by definition neutral and impartial. He serves a public and general interest which is, in the French voluntarist conception, 'absolute', that is completely independent from particular or private interests. ${ }^{86}$ This means that all interests entering from the outside into this 'shell' are extraneous. In contrast, in the Anglo-Saxon tradition of governance, the public interest is seen as flowing from the confrontation of competing goods, including private interests. ${ }^{87}$

To conclude the reflection on 'due' and interfering 'undue' interests: for sure, we do not expect and do not want decision-makers to exercise their judgement in a social vacuum. They should not be completely disinterested. But they should not allow undue, 'alien' interests to impact on the decision. A conflicted decision-maker is someone who is for one of the mentioned reasons prone to letting such undue interests influence his or her decision.

\footnotetext{
${ }^{84}$ See Art. 12 of the Swiss Loi fédérale sur la libre circulation des avocats (SR 935.61), 23 June 2000: 'Rules of Professional Conduct: The following rules of professional conduct are applicable to lawyers: a. They shall exercise their profession conscientiously and with diligence. $b$. They shall exercise their profession independently, in their own names and on their own responsibility. c. They shall avoid every conflict of interest between that of client and persons with whom they have business or private relations' (translated into English by the Council of Bars and Law Societies of Europe).

${ }^{85}$ Guzzetta, 'Legal Standards and Ethical Norms', p. 24.

86 Commission de réflexion (n 28), p. $66 .{ }_{87}$ Cf. Weale, 'Public Interest', p. 833
} 


\section{Undue personal interests}

The prototypical case of undue interests in that sense are personal interests of the holder of a public office who has to take formal decisions for the state, for example on construction permits. ${ }^{88}$ The idea of conflict of interest rests on the premise that such personal interests should not bear on the outcome of the decision. Consequently, the traditional narrow understanding of conflict of interest facused on the conflict between an office-holder's obligation to take decisions in the public interest and his personal, notably pecuniary interests. In that sense, the OECD has defined as follows: "A "conflict of interest" involves a conflict between the public duty and private interests of a public official, in which the public official has private-capacity interests which could improperly influence the performance of their official duties and responsibilities. ${ }^{.89}$ Along the same line, the Council of Europe's recommendation on Codes for public officials of 2000 states: '1. Conflict of interest arises from a situation in which the public official has a private interest which is such as to influence, or appear to influence, the impartial and objective performance of his or her official duties. ${ }^{90}$ The OECD definition has become canonical, and has been used as a starting point in subsequent studies and reports on conflict of interest. ${ }^{91}$

With regard to the private-law sphere of corporate governance and the professions, conflicts may arise which have the same structure as the 'OECD-constellation'. Here a conflict of interest is present when a

${ }^{88}$ Cf. the case study by Dobler, 'Private vices, public benefits? Small town bureaucratisation in Namibia', Chapter 12 in this volume.

89 OECD, Managing Conflict of Interest. See in scholarship Hejka-Ekins, "Conflict of Interest', p. 481: 'Situations where public employees encounter opportunities to use their public office for the sake of their own private gain.' Warren perceives a conflict of interest 'when a public servant uses an office for personal gain by paying special favors to private interests in exchange for payments of some kind (money, products, services)' and 'when a public official uses governmental position to benefit individual private interests (commonly, private business interests) or the interests of the government worker's family or friends.' Warren, Administrative Law, p. 175.

90 Committee of Ministers of the Council of Europe, Recommendation on Codes of conduct for public officials, Recommendation 10 of 11 May 2000, Art. 13 - Conflict of interest.

${ }^{91}$ Relying on the OECD definition, e.g. Commission de reflexion (n 28), p. 13. The commission then goes on to define conflict of interest (for a public agent) as following: 'Un conflit d'intérêt est une situation d'interférence entre une mission de service et l'intérêt privé d'une personne qui concourt à l'exercise de cette mission, lorsque cet intérêt, par sa nature et son intensité, peut raisonnablement être regardé comme étant de nature à influencer ou paraitre influencer l'exercise indépendant, impartial et objectif de ses fonctions' (ibid., p. 19). professional's decisions which he should take solely with respect for the contractual and legal obligations and the professional standards governing his activity are unduly influenced by his private interests. For example, the director of a firm who extends a contract offer to the enterprise managed by a friend and not to the best qualified supplier is prone to being influenced by his private relationship.

But the matter is more complicated, because not all private interests are inevitably 'undue' interests which taint the decision-making processes and should therefore be strictly banned. For example, although a requirement of any employment and of public office is that the employee or the office-holder should work for the good of the organisation (or of the relevant community), the decision-maker's secondary interest in individual promotion and success is in principle considered equally legitimate. ${ }^{92}$ In fact, this secondary interest may be a powerful stimulus for performing a good job for the organisation or employer. So it could be said that the secondary interest here is not in 'conflict' with the primary one but on the contrary reinforces it. ${ }^{93}$ However, that secondary interest in promotion, success, and making money can turn itself against the primary interest if remuneration schemes incite agents to take too risky decisions. This problem will be discussed next.

\section{Undue financial interests}

An important potential for conflict of interest in form of a temptation to let a personal pecuniary interest impact (in a detrimental fashion) on a professional or official decision lies in financial arrangements and compensation schemes. According to a recent study on conflict of interest in the financial sector, compensation schemes are one of the main sources of conflicts of interest here. ${ }^{94}$ Indeed, financial incentives may attract the wrong type of people to the job, or they crowd out other values such as integrity and intrinsic motivation. ${ }^{95}$ Managers may feel tempted to 'cook the book' and engage in fraudulent activities to boost their profits. ${ }^{96}$ Performance-based remuneration of managers may also lead them to engineer false expectations and to create an appearance of

92 Hejka-Ekins, 'Conflict of Interest', p. 482.

93 Friedberg, 'Sociology of organised action', Chapter 2 in this volume, p. 50.

${ }_{94}$ Thévenoz and Bahar, Conflict of Interest, p. $8 .{ }_{95}$ Ibid., p. 12.

${ }^{96}$ See in detail Handschin, "Conflict of interests related to management and board payments - profit-based remuneration systems make things worse', Chapter 16 in this volume. 
overperformance. As a result, the entire market may lose confidence in the accuracy of financial reports on the performance of companies. Also asset managers are subject to wrong incentives through the structure of their compensation. These favour 'churning portfolios', i.e. generating excessive trading to increase revenue. Finally, financial analysts' remuneration schemes for their research may generate conflict of interest. The analysts' earnings forecasts will be influenced by their desire to attract investment banking clients if their bonuses depend on the overall performance of the firm. ${ }^{97}$ Only recently, the business world has developed sufficient sensibility for these at-risk situations.

More generally, already the fact that someone (either the person or group to whom the fiduciary obligation is owed, or a third party) pays might cause a conflict of interest: 'He who pays the piper calls the tune' or, in German: 'Wess Brot ich ess, des Lied ich spiel'. The danger of an indirect distortion of judgement through financial dependency is especially obnoxious for all decision-makers whose task it is to adjudicate, i.e. to settle disputes between two parties. These are in the public sphere the judges, in global governance international judges and quasi-judges such as human rights treaty body members, ${ }^{98}$ and in the private and semi-private sphere arbitrators. ${ }^{99}$ The work of these dispute-settlers, which need not only be independent, but additionally impartial, will be discussed in detail in Chapter 19.

Moreover, the requirement of independence, especially financial independence, is crucial to guarantee the performance of jobs which do not consist in adjudicating between two parties but which still require an objective assessment, such as bond rating firms and auditors. A recent study found that conflicts of interest in auditing 'have become truly egregious. ${ }^{100}$ The mere danger of not being hired any more in the future if a negative audit prediction is delivered leads to practices showing the auditors' disposition to produce positive results, for example 'lowballing. ${ }^{101}$ That study identified two main factors which exacerbate the risk of conflict: the small size of the auditing firm ${ }^{102}$ and a long-standing

97 Palazzo and Rethel, 'Conflicts of Interest', pp. 16-17.

${ }_{98}$ Davala, 'Conflict of interest in universal human rights bodies', Chapter 7 in this volume.

99 See in detail Reinisch and Knahr, 'Conflict of interest in international investment arbitration', Chapter 6 in this volume; Peters, 'Managing conflict of interest', Chapter 19 in this volume, at pp. 364-368.

100 Moore et al., 'Conflicts of Interest and the Case of Auditor Independence', p. 11

101 Moore et al.

102 The likelihood of delivering whitewashed reports in order to establish a long relationship decreases with the growing size of an auditing company. relationship with the client. ${ }^{103}$ Because of proneness of auditors to conflict of interest, the EU Commission in 2002 adopted a set of fundamental principles on statutory auditors' independence in the EU. ${ }^{104}$ Here the Commission highlighted that 'the independence of statutory auditors is fundamental to the public confidence in the reliability of statutory auditors' reports. ${ }^{105}$ The Commission directive contains rules on how to deal with 'independence threats and risks', including self-interest. ${ }^{106}$

\section{Undue non-personal interests}

Some students of the issue and some regulators apply a narrow concept of conflict of interest and define as a conflict of interest only those situations where the intervening secondary interest is a personal interest of the decision-maker, hence an interest held directly or indirectly by him. ${ }^{107}$

In contrast, this volume also deals with settings where the intervening secondary interest is a public or professional interest. Benjamin Schindler, in this volume, distinguishes two main types of undesirable or undue interests, personal interests of public officials and particular (as opposed to general) interests, for example the interests of farmers seeking subsidies (as opposed to the entire population), or of specific industries. ${ }^{108}$

Taking the concept even one step further than Schindler, it is submitted that public or professional interests (as opposed to purely personal interests) may in a concrete decision-making context be 'undue' as well, and even if they are not only 'particular' interests. For example, the city of Zurich's police prohibited the local shopkeepers to sell alcohol-to-go across the counters during a soccer match for fear of hooliganism. This

${ }^{103}$ Independence decreases with the longer lasting relationship, because a common identity among auditor and client is formed.

104 'Statutory Auditors' Independence in the EU: A Set of Fundamental Principles', EU Commission recommendation of 16 May 2002, Doc. No. C (2002) 1873, Of 2002 L 191/222.

105 Ibid., Preamble, para. 2.

106 To that end, the Commission Directive prescribes, inter alia, the disposal of financial interests of auditors that might threaten auditor independence, the prohibition of business relationships between auditors and client, the exclusion of dual employment in the audit firm and its client, the exclusion of a managerial or supervisory role of the auditor over its client, the exclusion of employment of a director or manager of the client in the audit firm, and finally the exclusion from an audit team of an auditor with family or other personal relationships to the client.

107 See in this sense Commission de réflexion (n 28), pp. 17-18; Part 1, s. 4 of the Canadian Conflict of Interest Act, Statutes of Canada 2006, chapter 9, section 2.

108 Schindler, 'Conflict of interest and the administration of public affairs - a Swiss perspective', Chapter 9 in this volume. 
administrative prohibition was qualified as illegal by the administrative tribunal. The reason was that in this concrete regulatory context, taking into account the general interest in safeguarding public order in the street should not have entered the discretionary decision concerning the licence to run a restaurant, because it was simply not sufficiently related to the legislative objective of the relevant local statute on restaurants and thus should not be allowed to influence the implementation of that statute. ${ }^{109}$

Non-personal, but nevertheless 'undue' interests are especially relevant for those decision-makers whose institutional role is to be a neutral arbiter between two antagonist parties, such as a judge. Although sociologically, the person of the judge can hardly be impartial, the judge (as an office) by legal definition is. ${ }^{110}$ Here a typical source of conflict of interest is previous and current activity of judges, including publications and statements in the media. Such activity often manifests the decisionmaker's attitude on certain issues and therefore gives rise to the suspicion that his opinion has already been formed, which would betray his institutional function.

\subsection{Multiple roles or multiple principals}

A second type of conflict of interest arises when a decision-maker simultaneously fulfils two (acknowledged and official) roles, where individuals 'wear two hats' at a time. ${ }^{111}$ The traditional constitutionalist concept of separation of powers in states (between the legislative, executive and adjudicative power) seeks exactly to forestall these kinds of role conflicts (and the ensuing conflict of interest). An example for the conflict arising out of two accepted roles is the activity of Swiss parliamentarians deciding on the admissibility of a popular initiative as judges, while remaining politicians with an ideological and strategical agenda. ${ }^{112}$

Wearing two hats is especially prone to generate conflict of interest, when this comprises on the one hand neutral activity and on the other hand a partial activity. The prime example is a university teacher who must grade his or her students, but also write recommendations for

109 Administrative Tribunal (Verwaltungsgericht) of the Canton Zurich, decision of 20 August 2008, VB.2008.00183.

110 See in detail on the impartiality of judges Peters, 'Managing conflict of interest', Chapter 19 in this volume, pp. 371-379.

111 Stark, 'Comparing Conflict of Interest', pp. 336-341; Shapiro, Tangled Loyalties, pp. 4-5.

112 Christmann, 'Politicians as judges? Conflict of interest in the Swiss Parliament during decisions on the validity of popular initiatives', Chapter 11 in this volume. them to push them on the job market. Also, the professors' grading might be influenced by their desire to attract students (a desire which is fostered by modern universities' performance-based allocation of resources to the teacher), and to be popular among students.

A third type of conflict of interest exists when a decision-maker serves two different principals. Palazzo and Rethel have called this an 'impersonal conflict of interest' or a 'principal-principal conflict', where 'agents are confronted with colliding interests of different principals. ${ }^{113}$ Unlike in the first type of conflict, here the interests (towards both sides) are primary, because they are central to the fiduciary relationships. ${ }^{114}$

Principal-principal conflicts of interest raise moral concern because such conflicts make it more difficult for the agent to be objective in evaluating the interests of both sides; thus, the clients are less certain that the agent will act in their best interest. ${ }^{115}$ Of course this principalprincipal conflict may coincide with a conflict of the first type; the agent may additionally be driven by the desire to obtain personal gains.

The prototype of a principal-principal conflict is the situation of a legal counsellor who counsels both adversaries in a litigation. ${ }^{116}$ Another example would be the member of a company's board of directors who at the same time represents a huge creditor of that company. And because a typical source of conflict arising from multiple principals is side-employment, most statutes on the civil service and public officials proscribe ancillary private employment. ${ }^{117}$

113 Palazzo and Rethel, 'Conflicts of Interest', p.12.

114 'It need not, of course, actually be the case that one or the other interest, in a conflict of interest, be illegitimate or illegal; the claim of [this type of] a conflict is, rather, that it is morally wrong or illegal or illegitimate to serve both interests.' Margolis, 'Conflicting Interests', p. 362.

115 Hicks, 'Conflict of Interest', p. 183.

116 See Shapiro, Tangled Loyalties, chapter 5 'Other clients', pp. 134-169.

117 See for instance the French general statute on the public administration (Loi du 13 juillet 1983, statut général de la fonction publique), Art. 25: '1.-Les fonctionnaires et agents non titulaires de droit public consacrent l'intégralité de leur activité professionnelle aux tâches qui leur sont confiées. Ils ne peuvent exercer à titre professionnel une activité privée lucrative de quelque nature que ce soit.' (Amended by loi nº $2009-972$ du 3 août 2009 - Art. 33; loi no 2009-972 dı 3 août 2009 - Art. 34). See for Switzerland Loi du 21 mars 1997 sur l'organisation du gouvernement et de l'administration (LOGA) of 21 March 1997 (RS 172.010), Art. 60 ('Incompatibilité à raison de la fonction'); for the Swiss federal judiciary: Loi du 17 juin 2005 sur le Tribunal fédéral (LTF) (RS 173.110), Art. 6 ('Incompatibilité à raison de la fonction'). See for the US: Office of Government Ethics, Report to the President and to Congressional Committees on the Conflict of Interest Laws Relating to Executive Branch Employment (Washington DC, January 2006). 
Susan Shapiro relates that Supreme Court Justice Louis Brandeis was, as a nominee, questioned by the US Senate on a transaction he had been involved in on various sides, representing the estate, and descendant, and the shareholders, and the heirs all at once. Brandeis was asked who exactly he represented in this case. Brandeis was said to have answered: 'I was the attorney for the situation."118 Today, due to heightened sensibilities and strict regulation, such lawyering 'for the situation' is in most legal systems no longer permitted.

The cases of fulfilling multiple roles, or of serving multiple principals, seen through the lenses of 'undue' interests, present themselves as just special cases of a type-one conflict. The interest of the actor with his second hat, or the interest of the other principal are, in concrete situations, 'undue?.

\section{Conflict of interest management as prevention of corruption and bribery - in all spheres of governance}

Current political concern over conflict of interest is fuelled by the insight that situations of conflict of interest contain a particularly high risk of corruption and bribery. Conflict of interest is a situation in which an alien or undue interest could improperly influence the public interest activities and decisions (or activities and decisions taken in the best interest of a private sector entity). The existence of a conflict of interest is not in itself unfair, but may hold a potential for unfair behaviour, in short: for corruption. Therefore, as the Australian Anti-Corruption Commission put it: ' $[F]$ ailure to identify, declare and manage a conflict of interest is where serious corruption often begins and this is why managing conflicts of interest is such an important corruption prevention strategy. ${ }^{119}$ Importantly, this strategy has been pursued across all spheres of governance, and is itself a manifestation of the ongoing blurring of the spheres (public and private, domestic and global).

\subsection{Corruption}

The term corruption is not a term of criminal law, but a sociological one. Corruption is a shorthand reference for a range of illicit or illegal activities. Corruption is, in short, the abuse of authority (be it granted

${ }_{119}$ Shapiro, Tangled Loyalties, p. 80.

19 Independent Commission against Corruption and Crime, Managing Public Ethics in the Public Sector, Guidelines (Sydney, 2004), p. 7 in the public sphere or in the private sphere) for private purposes. ${ }^{120}$ Originally, the term corruption was used to designate the abuse of public authority ${ }^{121}$ Along that line, a definition by Transparency International, the leading NGO in the global anti-corruption effort, is: 'Corruption involves behaviour on the part of officials in the public sector, whether politicians or civil servants, in which they improperly and unlawfully enrich themselves and/or those close to them, or induce other to do so, by misusing the position in which they are placed. ${ }^{122}$

Since the 1990s, the concept of corruption has been extended to the private sphere. Notably the Council of Europe's Civil Law Convention on Corruption defines 'corruption' as including the private sector, in the following terms: "Corruption" means requesting, offering, giving or accepting, directly or indirectly, a bribe or any other undue advantage or prospect thereof, which distorts the proper performance of any duty or behaviour required of the recipient of the bribe, the undue advantage or the prospect thereof. ${ }^{123}$ Also the United Nations Convention against Corruption (UNCAC) of 2003 regulates corruption both in the public and in the private sector.

UNCAC lists the prevention of conflict of interest as one of the 'preventive measures' to combat corruption. With regard to public officials, the Convention foresees the adoption of codes of conduct, as 'measures and systems requiring public officials to make declarations to appropriate authorities regarding, inter alia, their outside activities, employment, investment, assets and substantial gifts or benefits from which a conflict of interest may result with respect to their function as public officials. ${ }^{124}$ With regard to the private sector, the Convention suggests to state parties 'the development of standards and procedures designed to safeguard the integrity of relevant private entities, including codes of conduct for ... the prevention of conflicts of interest. ${ }^{125}$ Anti-corruption measures may

${ }^{120}$ Pieth, 'Korruption', para. 14

${ }_{121}$ The widely accepted definition of corruption proposed by the World Bank is: 'The abuse of public office for private gain' (World Bank Group, Helping Countries Combat Corruption: The Role of the World Bank (September 1997), p. 8 (emphasis added).

122 Jeremy Pope (ed.), The Transparency International Sourcebook, p. 1 (emphasis added).

123 Art. 2 Civil Law Convention on Corruption, ETS No. 174 of 4 November 1999 (emphasis added).

124 Art. 8 s. 5 United Nations Convention against Corruption of 31 October 2003 (UNCAC), entered into force on 14 December 2005, United Nations Treaty Series, vol. 2349 , p. 41; UN-Doc. A/58/422.

125 Art. 12 s. 2 lit. e) UNCAC. 
include 'preventing conflicts of interest by imposing restrictions, as appropriate and for a reasonable period of time, on the professional activities of former public officials or on the employment of public officials by the private sector after their resignation or retirement, where such activities or employment relate directly to functions held or supervised by those public officials during their tenure. ${ }^{126}$

Corruption has been acknowledged as one of the most important obstacles to sustainable development and the rule of law. ${ }^{127}$ For example, both Council of Europe Conventions on Corruption emphasise 'that corruption represents a major threat to the rule of law, democracy, and human rights, fairness and social justice, hinders economic development and endangers the proper functioning of market economics. ${ }^{128}$ Combating corruption is therefore a high priority of global politics and governance, ultimately in the interest of global peace, the international rule of law, prosperity, and human well-being. Preventing corruption must start by addressing the situations favouring it, notably situations of conflict of interest.

\subsection{Bribery as a criminal form of corruption}

The offer of bribes often creates a conflict of interest, because the bribed person has an interest in receiving and keeping the bribe. When a decision-maker accepts a bribe, he succumbs to the 'undue' interest and allows it to 'taint' his decision - independently of whether the outcome (the decision itself) is in conformity with the law, and factually correct. $^{129}$ Combating bribery is therefore one clear-cut and traditional strategy in the broad field of conflict of interest regulation. The French criminal offence of 'unlawful taking of interests' ("prise illégale d'intérêts') is an illustration of that connection. ${ }^{130}$ 'Unlawful taking of interests' is a

126 Ibid.

127 Foreword by Secretary-General Kofi Annan to the UNCAC 2003: 'Corruption undermines democracy and the rule of law ... is a major obstacle to poverty alleviation and development.' See in this sense also the preamble of GA Res. 58/4 of 31 October 2003 (endorsing UNCAC), and the preamble of UNCAC itself. In scholarship Nadakavukaren Schefer, 'Causation'.

${ }^{128}$ There is an identical paragraph in the preambles of Council of Europe, Criminal Law Convention on Corruption, ETS No. 173 (of 27 January 1999); Civil Law Convention on Corruption, ETS No. 174 (of 4 November 1999).

129 See in detail on motives, appreciation, and process, Peters, 'Managing conflict of See in detail on motives, appreciation, and proce
interest', Chapter 19 in this volume, pp. 364-371.

130 French criminal code (Code pénal), consolidated version of 19 May 2011, para. 3 on 'unlawful taking of interests' ('De la prise illégale d'intérêts'), Art. 432-12: 'The taking, specific French infraction for public officials, which is unique among OECD countries. French courts and administrative tribunals have interpreted it broadly, and applied it in a sweeping manner, with stiff penalties. The notion 'intérêt quelconque' (any interest whatever) criminalises the taking into consideration of all kinds of alien interests, independent of their intensity or lacking intensity. ${ }^{131}$

The legal approach to bribery manifests an erosion of the various spheres of governance: public and private, national and international. After the break-down of socialist regimes in Eastern Europe, and the rise of Africa and Asia as production and investment sites it became apparent that a harmonised legal regime of bribery of foreign officials would be needed to level the playing field for the corporations of the capital exporting states of the North and West. Levelling that playing field was the main rationale for the elaboration of the OECD Anti-bribery Convention which was adopted in 1997 . Thereby, part of the regulation of bribery has been transferred to the international level. Both levels of governance, international and domestic, must now play together.

A second boundary, the one between public and private, has been blurred as well. Initially, bribery was understood as necessarily involving bribing a public officer. For example, the OECD Anti-bribery Convention of 1997 only addresses the bribery of (foreign) public officials, and only the action of the person who promises or gives the bribe (so-called active bribery), not on the receiver's side (so-called passive bribery). ${ }^{132}$

receiving or keeping of any interest [un intérêt quelconque] in a business or business operation, either directly or indirectly, by a person holding public authority or discharging a public service mission, or by a person holding a public electoral mandate who at the time in question has the duty of ensuring, in whole or in part, its supervision, management, liquidation or payment, is punished by five years' imprisonment and a fine of $€ 75,000^{\prime}$ (emphasis added).

131 Commission de réflexion (n 28), pp. 30-40.

132 The OECD Convention endorses the following definition of bribery: It is an offence of bribery 'for any person intentionally to offer, promise or give any undue pecuniary or other advantage, whether directly or through intermeciaries, to a ... public official, for that official or for a third party, in order that the official act or refrain from acting in relation to the performance of official duties, in order to obtain or retain business or other improper advantage? Art. 1 sec. 1 of OECD Convention on Combating Bribery of Foreign Public Officials in International Business Transactions, signed on 17 December 1997, entered into force on 15 February 1999. So the OECD Convention does not seek the criminalisation of the conflicted person, but only of the briber who induced the conflict. It is immaterial whether the official in fact takes the decision expected by him. He does not even need to be aware that he has been offered such an advantage with thi aim in mind. The criminal act of active bribery is, according to the OECD Convention, 
With the wave of privatisations in the 1990s (i.e. the choice of a private law-cloth for public institutions, the increased for-profit economic engagement of states, the outsourcing of tasks performed in the public interests and the dissolution of former state monopolies in infrastructure), the limitation of the offence of bribing to the formally public sphere was realised as being too narrow. The Council of Europe Criminal Law Convention on Corruption of 1999 obliges states parties to establish as criminal offences under their domestic law both active and passive bribery in the private sector. ${ }^{133}$ In consequence, numerous states introduced such offences. In those jurisdictions, it is a criminal offence for persons who direct, or work for, private sector entities, to request or receive undue advantages in order to act or refrain from acting in breach of their (private law-based, normally contractual) duties for their employer or firm. ${ }^{134}$ With the extension of this offence, the legislators have reacted to the increasing blurriness of the spheres of public and private law and governance, and have themselves contributed to it.

The result is that, from the perspective of many jurisdictions, and from an international law perspective, bribery can occur in all spheres of governance: public, private, and global. Indeed, both the UN Convention against Corruption of $2003,{ }^{135}$ and the Council

completed when the briber has offered, promised, or given, the undue advantage to the official with the intention that the official direct his acts to the goal intended by the bribe. Zerbes, 'Commentary on Article 1', pp. 136-137.

133 Arts. 7 and 8 of the Council of Europe Criminal Law Convention on Corruption, ETS No. 173 (27 January 1999).

134 The offence of private bribery has been introduced in the UK, France, Germany, Austria and Switzerland. See for the UK the Bribery Act 2010, of 8 April 2010 (chapter 23), ss. 1-3 (s. 2(3)(b) states that the relevant activity of the bribed person can be 'any activity connected with a business'). Switzerland has conceptualised this as a crimina act against fair competition (Art.4a 'Corruption active et passive') in the Loi fédérale du 19 décembre 1986 contre la concurrence déloyale (LCD), RS 241. The US oppose such an offence. See Heine, Huber and Rose (eds.), Private Commercial Bribery.

135 Arts. 15, 16, and 21 UNCAC. UNCAC first defines bribery of national public officials as (a) The promise, offering or giving, to a public official, directly or indirectly, of an undue advantage, for the official himself or herself or another person or entity, in order that the official act or refrain from acting in the exercise of his or her official duties; (b) The solicitation or acceptance by a public official, directly or indirectly, of an undue advantage, for the official himself or herself or another person or entity, in order that the official act or refrain from acting in the exercise of his or her official duties' (Art. 15 UNCAC). The Convention then goes on to define the bribery of foreign public officials, of officials of public international organisations (Art. 16 UNCAC), and in the private sector (Art. 21) in a similar way. of Europe Criminal Law Convention on Corruption of $1999^{136}$ address bribery in all three spheres.

\section{Why study conflict of interest?}

The difficulty of managing, and indeed already of defining conflict of interest, to some extent has to do with evolving attitudes and expectations of the general public. The pure fact of formulating the concept of conflict of interest is in itself a sign of a political (and corporate) culture profoundly impregnated by a concern for justice. There is no conflict of interest where the law confounds itself with the interest of the most powerful. The holder of power is not in conflict with himself. ${ }^{137}$ In the last decades, the public standard of morality has become stricter. 'Previously acceptable conduct ... is now deemed unethical and previously unethical conduct is now deemed criminal. ${ }^{138}$

But is public concern about a putative decline of ethics of public officials (or of bankers and managers) a distorted perception? The general worry might exceed the formal evidence of unethical behaviour, partly because of increased media coverage. In fact, it is difficult to find empirically whether conflict of interest is really increasing, or whether only its perception is more acute. Activities of regulators on all levels of governance have been mostly 'scandal-driven'. Corporate breakdowns, the global financial crisis and numerous political scandals, have been imputed to conflicts of interest besetting decision-makers. But is this imputation justified? A comparative study on conflict of interest of high public officials in European states found 'no evidence that conflicts of interest are increasing as such.'139

Still, current trends in governance suggest that there is indeed a real potential for more conflict of interest, and that conflict of interest is not just a chimera. In times of globalisation, conflict of interest has become a structural problem of decision-making and thus of governance. The first reason is that globalisation implies on the one side interconnectedness, organisational growth and concentration of power in some hands, but

136 Arts. 2-11 Council of Eutope Criminal Law Convention on Corruption, ETS No. 173 (27 January 1999). For example, Arts. 9-11 relate to bribery of officials of international organisations, international parliamentary assemblies, and international judges.

137 Dufresne, Conflits d'intérêts.

138 Anechiarico and Jacobs, The Pursuit of Absolute Integrity, p. 16.

139 Demmke et al., Regulating Conflicts of Interest, p. 138. 
on the other side also an increased division of labour, more specialisation and the need for a very high level of expertise. That demand for very special expertise in turn requires reliance on dense networks of initiated persons. It also favours the revolving door phenomenon, i.e. the quick shift of specialists from client to client, which includes their enhanced mobility between the public and private sector.

In the world of commercialised legal counselling, for example, law firms have become much bigger and spread over various countries and their (corporate) clients as well. The relationship between them is more anonymous. Law firms are selected not because of personal trust between client and attorney but based on the expertise of the entire firm. Often a client chooses a firm which represented the opposing side in a previous transaction because the client was impressed by that firm's performance. Also, clients hire not only one lawyer, but a number of specialised firms. For a huge law firm with subsidies, avoiding simultaneous or subsequent representation of various parties to a transaction or a litigation becomes difficult. Very strict and rigid self-regulation for lawyers representing parties in lawsuits, e.g. the rules by the Law Society of England and Wales on conflict of interest, with blanket prohibitions for solicitors of simultaneous and successive representation of certain clients, are for these reasons perceived to be outdated, 'out of touch with commercial reality', and are therefore not complied with by the law firms (by their own account). ${ }^{140}$

In line with the new demands, public administration has evolved. Generally speaking, the more the administrative activity moves beyond the traditional role of autonomous-top-down enforcement of objectives, public interests clearly defined by statutory law, the more the administration is entrusted with balancing interests and resolving conflicts, the more administrative and organisational safeguards of impartiality, including conflict of interest management, are needed. ${ }^{141}$

Additionally, the ideals of 'new public management' have transformed the administration in the direction of decentralised public services, with an improved customer and citizen orientation, which has moreover outsourced some tasks. In particular, the new forms of relationships between the public sector, business and NGOs (public-private-partnerships, multi-stakeholder initiatives and sponsorships), have decreased the distance and thus the independence of the societal actors from each other. But the involvement of private actors in public administration is

\footnotetext{
${ }^{140}$ Griffiths-Baker, Serving Two Masters, p. 174. $\quad{ }_{141}^{14}$ Fehling, Verwaltung, p. 510.
}

ambivalent. Their private personal interests are on the one hand a risk for the impartial pursuance of the public good. On the other hand, the actor's self-interestedness is also a powerful stimulus, which can and is indeed instrumentalised in order to obtain a more effective and efficient performance of administrative tasks. ${ }^{142}$

All these interlinked phenomena create new options for undue influence and thus bear the potential for new forms of conflict of interest. So maybe the question must be studied separately for sub-issues of conflict of interest. It is - for example - likely that conflict of interest due to postoffice private employment of former public officials is increasing, and also conflict of interest due to secondary activities of office-holders. ${ }^{143}$

The whole issue has therefore on good ground attracted scholarly interest. Recent sociological, legal and philosophical scholarship has either studied conflict of interest in specific professions, ${ }^{144}$ in corporate governance ${ }^{145}$ or in the financial services sector. ${ }^{146}$ In private law, specific questions such as self-contracting have been studied. ${ }^{147}$ With regard to ethics in the professions, several works relate to legal practice, ranging from handbooks on the law as it stands in a particular jurisdiction ${ }^{148}$ to sociological studies. ${ }^{149}$

142 Ibid., pp. 354 and 511

143 Demmke et al., Regulating Conflicts of Interest, p. 122.

144 Davis and Stark (eds.), Conflict of Interest in the Professions studies conflict of interest, from a multidisciplinary perspective, in a host of professions ranging from journalism over engineering and academics to health care. Moore et al. (eds.), Conflicts of Interest studies the issue in various professions, mostly from a business administration and psychological perspective.

145 See on stock corporations under Swiss law Lazopoulos, Interessenkonflikte und Verantwortlichkeit des fiduziarischen Verwaltungsrates, on stock corporations under German law: Krebs, Interessenkonflikte bei Aufsichtstatsmandaten in der Aktiengesellschaft Baumanns, Rechtsfolgen einer Interessenkollision bei AG-Vorstandsmitgliedern; on stock corporations under French law: Dominique Schmidt, Les conflits d'intérêts dans la société anonyme.

146 Chizu Nakajima and Elisabeth Sheffield, Conflicts of Interest and Chinese Walls; Crockett et al., Conflicts of Interest in the Financial Services Industry, covering investment banking, accounting, rating agencies, and universal banking. Thévenoz and Bahar, Conflict of Interest study corporate governance, in particular executive compensation, financial analysis, and asset managernent.

147 See for Swiss law Schott, Insichgeschäft und Interessenkonflikt, for a comparison of German and English law Festner, Interessenkonflikte im deutschen und englischen Vertretungsrecht.

148 Hollander and Salzedo, Conflicts of Interest is a handbook addressed at practitioners in the conflict of interest law for solicitors, barristers, accountants, financial estate agents and insurance brokers in England and Wales.

149 Shapiro, Tangled Loyalties concentrates on private law practice within the state of Illinois. Griffiths-Baker, Serving Two Masters is a study on solicitors in England and Wales. 
The most important academic works on conflict of interest in the public sphere (in the public administration and with regard to political office-holders) have focused on the United States, where the concept has been developed already in the nineteenth century. ${ }^{150}$ The most comprehensive comparative survey is a 2007 study conducted on the relevant rules for the holders of higher public and political office (excluding ordinary public employees or civil servants) in the EU-27 and the EU institutions, carried out on behalf of the European Commission Bureau of European Policy Advisers. ${ }^{151}$ Other comparative investigation on conflict of interest regulation has been conducted notably with regard to European states, the US, and Canada. ${ }^{152}$

Conflict of interest is an intriguing subject of research because it is a borderline concept in the intersection of law and morality. This situatedness in itself immediately raises the deep question of the limits of the law and of regulation, and underscores the importance of the cultural context for regulation. For sure, conflict of interest requires an interdisciplinary study, using legal, sociological, psychological, philosophical, and economic methods.

Secondly, conflict of interest is an intriguing subject of study because it is elusive and difficult to seize. It is difficult to define in the abstract

150 See the classic study by the Association of the Bar of the City of New York: Special Committee on the Federal Conflict of Interest Laws, Conflict of Interest and Federal Service. See more recently Stark, Conflict of Interest in American Public Life.

${ }^{151}$ Service. See more recently Stark, Conflict of Interest in American Public Life.
Demmke et al., Regulating Conflicts of Interest. That study analyses the laws, regulations, and codes of conduct for members of government, members of parliament, judges of highest courts, members or directors of courts of audit and cen parliament, judges of EU member states and the EU institutions. It was cartional banks in ers from the European Institute of Public Administration, various European universities, in cooperation with the European Public Administration Network which is composed of governmental officials from all EU member states.

152 Saint-Martin and Thompson, Public Ethics and Governance (mostly from a political science perspective); Ministry of the Interior and Kingdom Relations of a political lands/Utrecht School of Governance, Catalogue of promising practices in the fitd of integrity, anti-corruption and administrative measures against organized crime in the EU (The Hague, 2008); OECD and Manuel Villoria-Mendieta, Conflict of Interest Policies and Practices in Nine EU Member States: A Comparative Review, SIGMA papers No. 36 (Paris: OECD Publishing, 2005; also GOV/SIGMA(2006)I/REV1); Trost and Gash, Conflict of Interest and Public Life, comparing the conflict of interest regulation discourse in public governance across four Western democracies (US, UK, Canada and Italy) based on democratic theory. See for a specific conflict of interest constellation $\mathrm{OECD}$, Avoiding Conflict of Interest in Post-Employment: Comparative Overview of Prohibitions, Restrictions, and Implementing Measures in OECD-Countries, GOV/PGC/ ETH(2006)3 (Paris 26-27 January 2006). what a conflict of interest is, and how to know it when we see it. It may well be that the term is applied too generously, both in theory and in practice, and that this broadness rather obscures than illuminates the underlying problems we seek to address when using the term. ${ }^{153}$

Thirdly, the study of conflict of interest is important from the perceptive of regulatory theory. Overall, corporate, public, and criminal law approaches to conflict of interest, channelled by international rules, principles, and guidelines, are increasingly viewed as complementing each other. Worldwide, the overall regulatory approach is becoming holistic, involving private, administrative, and criminal law, domestic and international law, hard and soft law. This comprehensive approach is, it is submitted, in principle suited to manage the risk field of conflict of interest. However, while rules and codes have greatly increased in quantity, there is still insecurity about the right regulatory mix: until what point does selfregulation suffice? At which place must and may criminal law legitimately step in? There is also insecurity about the rules' quality: what are the right standards? Are there 'correct' standards across different spheres of governance, and across different legal and administrative and corporate cultures? Finally, there is insecurity about the appropriate density of regulation. Already, some observers consider the field to be over-regulated, and deplore the legalistic approach. Does not this manifest a decline of (or declining confidence in) generally shared and generally observed ethical standards of office-holders and professionals?

It seems that these questions can only be answered on the basis of cross-cutting analyses of the issue, which do not limit themselves to the traditional departments of corporate law, administrative law, and public international law. Therefore, conflict of interest needs to be studied in a comparative fashion, across different levels and sectors of governance. In settings apparently radically different such as the board of directors of an American or European multinationally active stock corporation, a town council in Africa or the staff of an international organisation, similar patterns and problems might be revealed. Inversely, comparative study might bring to light that the problems are too different in the different spheres to be meaningfully related to each other, and that no common solutions can be suggested. Ultimately therefore, this book is intended to exemplify the utility (or futility) of (comparative) governance studies.

\footnotetext{
${ }^{153}$ See for a discussion supra, pp. 4-6.
} 
This book approaches conflict of interest as a cross-cutting problem of governance. Concomitantly, it consists of five parts: I. General; II. Global governance; III. Public governance; IV. Corporate and financial governance and the professions; V. Conclusion. Within the General Part I, this chapter has established a common framework, followed by two conceptual chapters, authored by a sociologist and a philosopher, respectively (Chapters 2 and 3). Besides the various theoretical and systematic chapters, some chapters are based on empirical research, notably the chapters on public servants (Chapter 10, written by economists); of members of parliament (Chapter 11, written by a political scientist); on administrators and heads of government in developing countries (Chapters 12 and 13, authored by a social anthropologist and a lawyer, respectively), and on decision-making at the end of life (Chapter 18, written by a sociologist). Two chapters are saturated with the practical experience of the authors in international or corporate governance, notably Chapters 4 (written by a legal officer in the OECD), and Chapter 14 (written by a compliance practitioner).

The chapters identify when a conflict of interest is present, they investigate why and when it is a problem in that particular context (and when it is not). They explore mechanisms for managing the conflict, ranging from non-regulation over self- and co-regulation to contractual arrangements and statutory prohibitions accompanied by administrative fines or even penal sanctions. The concluding Chapter 19 draws together the insights from the various disciplines and systematises the findings relating to the different levels, types, and branches of governance.

\title{
Conflict of interest from the perspective of the sociology of organised action
}

\author{
ERHARD FRIEDBERG*
}

\section{Introduction}

Conflict of interest is a well-known phenomenon. It has a long history in the sociology of the professions, where it refers to situations where professionals with fiduciary duties to some other person (a client for a lawyer, a patient for a doctor, ${ }^{1}$ to mention the most analysed examples) are influenced in their professional practice by interests that are foreign to those of their clients and which therefore interfere with the proper exercise of their fiduciary duties. ${ }^{2}$ Conflict of interest is also a muchdiscussed notion today. In these days of stock-exchange scandals, demise of banks, high dependence on experts whose judgement and advice often does turn out to be biased by their own situational interests, widespread bouts of corruption even in the developed countries, and other ethical problems assailing our capitalist order, its use has been widened to be applied to situations outside of the classical profession. And most of the discussion takes on an ethical, if not a moralising tone, and seems to be emotionally and normatively loaded with reprobation and disapproval. The reference to conflict of interest designates not only situations where

* I want to thank Olivier Borraz, Frank Dobbin, Christine Musselin and Michael Storper, whose critical remarks and suggestions have helped me to improve a first version of this chapter. I also want to extend my special thanks to Daniel Högger whose editorial and bibliographical assistance was inestimable. As usual, I alone am responsible for the remaining errors and inadequacies of this chapter.

${ }^{1}$ See in this regard Shapiro, 'Conflict of interest at the bedside: surrogate decision-making

at the end of life', Chapter 18 in this volume.
2 This is more or less the sense of the canonical definition of conflict of interest by Davis and Stark: 'A person has a conflict of interest if, and only if, that person is in a relationship with another requiring the exercise of judgment on the other's behalf and that person has a (special) interest tending to interfere with the proper exercise of such judgment.' Davis, 'Introduction', p. 8. 